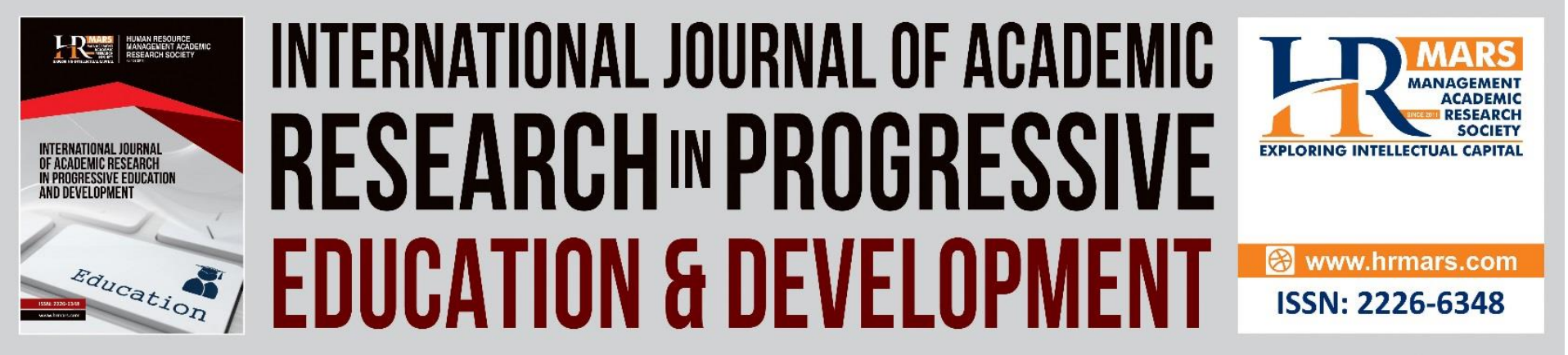

\title{
Effect of Using Flow Map Towards Mathematical Achievement and Higer Order Thinking Skills among Year Three Students
}

Mohd Afifi B. S., Logeswari K. R., A Rahim, N. A, Anis Norma, J., Syaza Hazwani, Z., Mohd Syaubari, O.

To Link this Article: http://dx.doi.org/10.6007/IJARPED/v11-i1/12212

DOI:10.6007/IJARPED/v11-i1/12212

Received: 09 November 2021, Revised: 14 December 2021, Accepted: 01 January 2022

Published Online: 20 January 2022

In-Text Citation: (Afifi et al., 2022)

To Cite this Article: Afifi, M. B. S., Logeswari, K. R., Rahim, A. N. A, Norma, A. J., Hazwani, S. Z., Syaubari, M. O. (2022). Effect of Using Flow Map Towards Mathematical Achievement and Higer Order Thinking Skills among Year Three Students. International Journal of Academic Research in Progressive Education and Development, 11(1), 761-770.

Copyright: (C) 2022 The Author(s)

Published by Human Resource Management Academic Research Society (www.hrmars.com)

This article is published under the Creative Commons Attribution (CC BY 4.0) license. Anyone may reproduce, distribute, translate and create derivative works of this article (for both commercial and non-commercial purposes), subject to full attribution to the original publication and authors. The full terms of this license may be seen

at: http://creativecommons.org/licences/by/4.0/legalcode

Vol. 11(1) 2022, Pg. 761 - 770

http://hrmars.com/index.php/pages/detail/IJARPED

JOURNAL HOMEPAGE

Full Terms \& Conditions of access and use can be found at http://hrmars.com/index.php/pages/detail/publication-ethics 


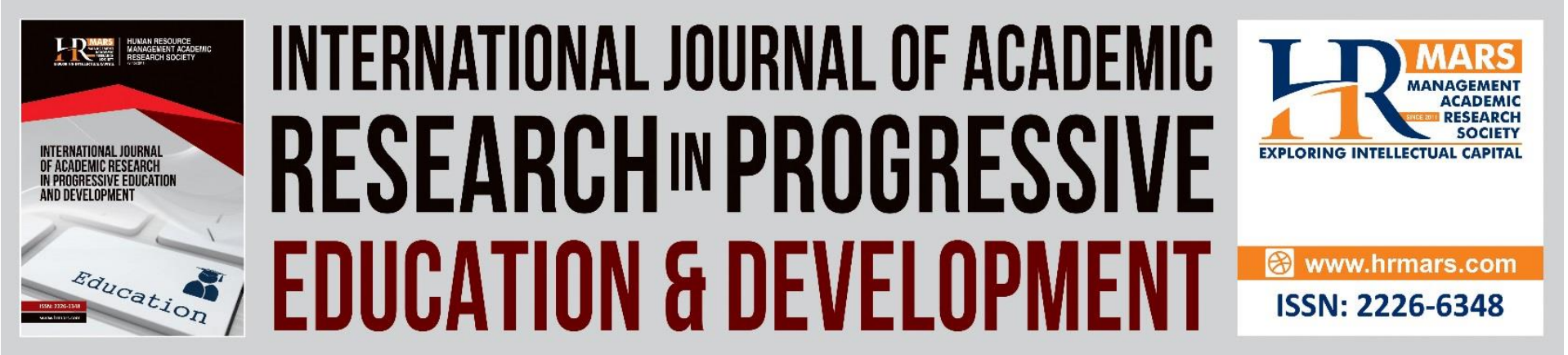

\title{
Effect of Using Flow Map Towards Mathematical Achievement and Higer Order Thinking Skills among Year Three Students
}

\author{
${ }^{1}$ Mohd Afifi B. S., ${ }^{2}$ Logeswari K. R., ${ }^{3}$ A Rahim, N. A, ${ }^{4}$ Anis \\ Norma, J., ${ }^{5}$ Syaza Hazwani, Z., ${ }^{6}$ Mohd Syaubari, O. \\ 1,2,4,5,6 Universiti Pendidikan Sultan Idris, ${ }^{3}$ Institut Pendidikan Guru Malaysia \\ Corresponding Author Email: mohdafifi@fpm.upsi.edu.my
}

\begin{abstract}
This study aimed to test the effect of flow charts on math achievement and thinking skills of third year students. A quasi -experimental design of unequal groups was used. A quasi experimental quantitative approach of unequal groups was used in this study. The selection of study participants was done by group random sampling to involve 60 third year students in a national school in Petaling District, Selangor. Respondents were divided into two groups, namely 30 students in the treatment group and 30 students in the control group. The study used two main instruments, namely the mathematical achievement test and the high -level thinking skills test. Data were analysed using t-test to see the mean difference. The findings showed that there were significant differences of post-test between the control group and the treatment group. The findings show that the flow chart method has a positive effect on the mathematical achievement test and the critical thinking skills test. In conclusion, the flow chart method can be used as an alternative method for students and teachers to solve sentence -length mathematical problem-solving questions. It is hoped that this study can be used as a reference and give implications to teachers' teaching methods. It is also hoped that this will support the efforts of the Ministry of Education Malaysia in achieving the aspirations of students.
\end{abstract}

Keywords: Mathematical Problem Solving, Flow Map Method, Higher Order Thinking Skills Mathematics Education, Mathematic Teaching Technique

\section{Introduction}

Human capital development is a National Mission that needs to be achieved. This aims to produce citizens who are knowledgeable, skilled, and highly skilled. In addition, students will be equipped with communication skills, leadership, information and communication technology skills, thinking skills and practice lifelong education (Ministry of Education Malaysia, 2006). The importance of developing human capital can be seen in the success of example countries such as Japan, South Korea, China and European countries. With knowledge, trained skills and high expertise, these countries have successfully developed their country. 
The Ministry of Education Malaysia (2007) through the National Strategic Plan for Higher Education outlines one of the seven main thrusts is to improve the quality of teaching and learning. This provides an opportunity for teachers, lecturers and educators to strive to form quality human capital. In line with current needs, students need to be able to be independent and take advantage of the learning session experience. The application of the elements of thinking skills in particular needs to be implemented so that the human capital that is born has added value so that they can be competitive in the job market later.

Improving the level of individual thinking skills is the first step in producing a group of thinkers. Thinking is a process that involves the human mind through the interweaving of knowledge, skills and values. Thinking skills are defined as the management of the mind while processing the information received whether in the form of knowledge, skills or values (Ministry of Education Malaysia, 1994). According to the Ministry of Education Malaysia (1994) again, thinking skills are divided into two groups, namely critical thinking skills and creative thinking skills. These skills occur when individuals use the mind in defining, generalizing, characterizing, analysing, predicting, interpreting, exploring and solving information or problems. These skills help individuals formulate opinions, generate ideas, critique, make mental pictures, draw conclusions and relate the information received. Thinking skills are also divided into elements of interpretation, evaluation, analysis, inference, explanation -making skills and self -control skills (Gelerstein et al., 2016). These skills can be applied through verse problem-solving questions in mathematics subjects.

In Malaysia, curriculum changes were implemented starting in 2011 by naming the curriculum as the Primary School Standard Curriculum (KSSR). The goal of KSSR in the subject of Mathematics is to develop students' understanding of basic counting skills and number concepts correctly. In addition, the KSSR curriculum also forms a balanced and competitive human being to the level of globalization. One of the subjects that can improve such thinking skills is mathematics. Hidayah and Zanaton (2017) stated that mathematics is a challenging subject especially for primary school students. At this level, mathematics is a core subject that emphasizes understanding of concepts, mathematical language, counting skills, problem solving skills and mastery of the noble values associated with Mathematics.

The operations of addition, subtraction, multiplication and division are the four basic operations that need to be mastered by students (Bachri \& Nurdyansyah, 2017). However, there is a constraint faced by most students that is lack in problem solving skills. Their failure to master problem -solving skills has disrupted the subsequent learning process and caused them to fail in primary school assessments. Analysis from the study of Ariffin and Aziz (2016) shows that there are non-routine question forms in problem solving questions. Non-routine questions require students to think outside the box and cause students to be less confident. Thus, there is a need for teachers to develop teaching aids that can help students master these skills. Teachers should create a variety of learning experiences in the classroom so that they can improve the level of knowledge and skills of students (Yap \& Rahaimah, 2018). This has been implemented by Afifi et al (2019) who have implemented innovations for teaching and learning approaches. The new technique or innovation developed is also expected to have a positive effect on students' critical thinking skills. Therefore, this study aims to test the effect of flow chart method on mathematical achievement (problem solving) and thinking skills of year 3 students. 


\section{Flow Map Method}

The Polya problem -solving model was introduced by a Hungarian mathematician named George Polya by publishing the book "How to solve it" in verse problem-solving questions. He describes four phases for good problem solving. However, the first phase is to understand the problem. Without understanding the meaning of the problem, students can plan strategies to solve the problem. There are various strategies such as trying to succeed, patterns, drawing pictures, using models, acting, making lists and so on. Next, implement appropriate strategies for solving sentence -length problems. The fourth phase is to review the solutions that have been completed. Therefore, the researchers still used the phases of the Polya model but modifications were made according to the level of understanding of the third-year students.

The flow chart method is a modification of the Polya (1957) model. This method is a method built specifically on mathematical sentence problem -solving questions for year three addition topics. The transformation of the Polya (1957) model to the flow chart method can be seen in Figure 1.

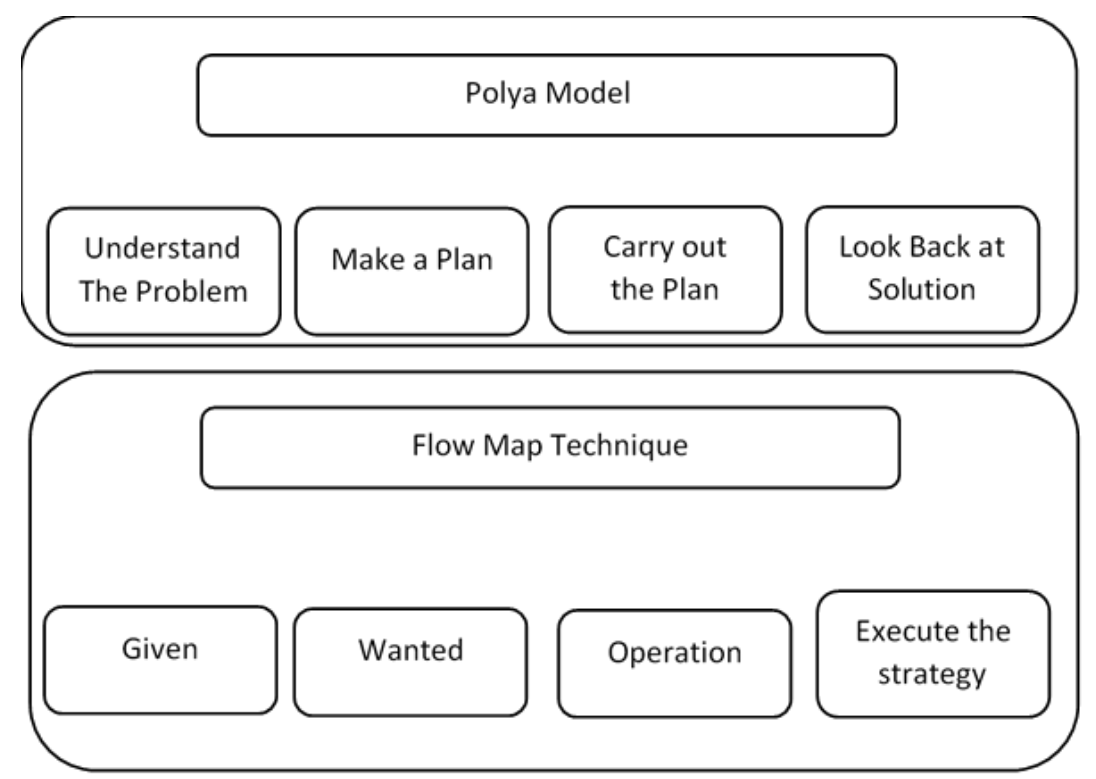

Figure 1. Flow Map Versus Polya Model

To explain the method of using this flow map, the researcher gave an example of a question that is "Mrs. Safiya bought 2632 white buttons and 3956 black buttons. How many buttons did Mrs. Safiya buy?."

In the first stage, the researcher names the initial steps as given. Here, students need to understand the sentence and gather the information given by the question.

Given: This means every piece of information needs to be listed.

Mrs. Safiya bought 2632 white buttons

Mrs. Safiya also bought 3956 black buttons

Wanted: At this second level, students need to write down what the question requires

Based on the sample of questions, then the amount sought

Operations: At this stage, students need to identify what operations need to be used

Based on the example, then the appropriate operation is addition 
DEVELOPMENT

Vol. 11, No. 1, 2022, E-ISSN: 2226-6348 @ 2022 HRMARS

Execute the strategy: At this stage, the student performs or completes the operation. This method has shown detailed steps that help students solve sentence-length math problems. The flow chart method is more appropriate and easier for students to understand. This method also focuses on information that can guide students to interpret the solution of verse problems more clearly.

\section{Methodology}

\section{Research Design}

To test the effect of this flow chart method, researchers have used a quasi -experimental design of uneven groups. The process began by dividing the study sample into two groups. The groups were called the treatment group and the control group. At the beginning of the study, researchers gave pre-math achievement tests and pre-tests of high-level thinking skills to both groups. The selection of an experimental method is appropriate if a study wants to look at the relationship between cause and effect (Fraenkal et al., 2012; Gay et al., 2009). The design of experimental studies is divided into two, namely true experiments and quasi experiments (Campbell \& Stanley, 1963; Cohen et al., 2007). Since the researchers did not randomly divide each group member, the researchers chose quasi -experimental as the study design. Interventions were given to both groups where the treatment group was taught using the flow chart method, while the control group used the conventional. The intervention lasted for 4 weeks. Upon completion of the fifth week, post-test of mathematics achievement and post-test of high-level thinking skills were given to both groups. The implementation of this study can be illustrated in Figure 2 .

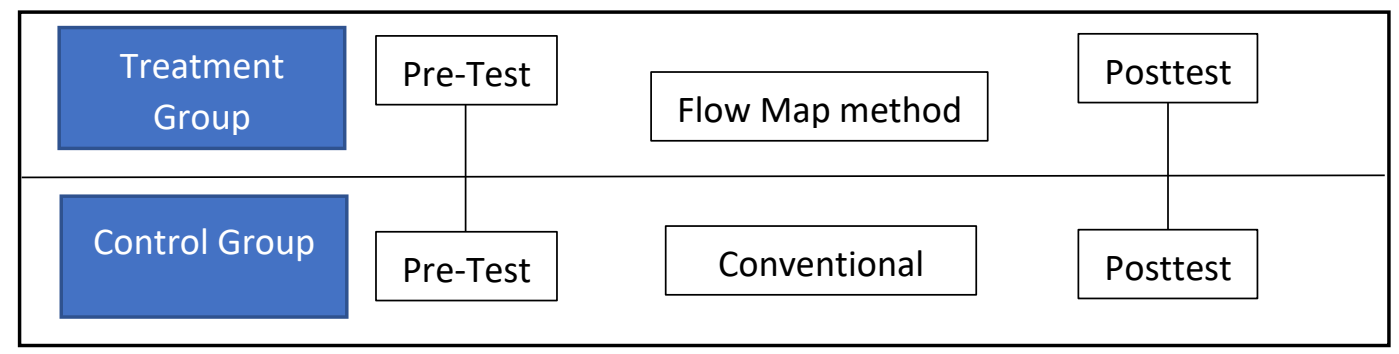

Figure 2. Implementation of the Study

\section{Population and Sample of the Study}

The population of this study is year 3 primary school students in Petaling district, Selangor. According to Creswell (2012), cluster sampling techniques can be implemented as follows. Researchers have chosen Selangor as the research location. In the state of Selangor, there are 9 districts. District selection was done using a simple random sampling technique through the fish bowl technique. The implementation of this election is done with the following steps:

Write a list of districts on torn white paper.

I. Roll up and Put the white paper in the container.

II. Select one paper to be the sample location (district).

This process is also carried out for the selection of schools in the Petaling district. 60 students have been selected. The students were then divided into two groups, namely 30 students in the control group and 30 students in the treatment group. 
DEVELOPMENT

Vol. 11 , No. 1, 2022, E-ISSN: 2226-6348 @ 2022 HRMARS

\section{Research Instruments}

The data collected in this study were mathematical achievement (addition) and high -level thinking skills. To collect the study data, the researchers have used the mathematical achievement test of the topic of addition and the test of high -level thinking skills in the topic of addition. The math achievement test and the thinking skills test contain 10 subjectively shaped questions. Researchers have implemented a validation process on both instruments. The value of content validity for both instruments is equal to 1 . The researcher has appointed 3 experts in the field of mathematics and 3 experts in the field of thinking skills during the content validation process. A pilot study was conducted and the reliability value of the instrument has exceeded 0.70 . So, the instrument has good validity and reliability

\section{Data Analysis Methods}

Researchers initially analysed the initial data with normality tests to determine the distribution of the data studied. Subsequent analysis was made based on the distribution of the data. The findings indicate that the data collected are normal based on significant values exceeding 0.05 for the Shapiro-Wilk test. This test is suitable for use to review the normality of data less than 100 (Coakes, 2007). Since the data were normal, the researchers used independent samples t-test and repeated measurement t-test to identify the difference between the mean.

\section{Findings}

The findings are explained through the hypotheses made. First, there was no significant difference in the mean of pre -test mathematical achievement and high -level thinking skills between the treatment group and the control group. Independent sample $t$-test analysis showed that there was no significant difference in pre -test mathematical achievement scores between the control group (mean $=2.40, \mathrm{sd}=0.50$ ) and the treatment group (mean $=2.63$, $s d=0.49), t(29)=-1.88, p \geq 0.05$ i.e. 0.70). The mean score difference between these two groups was 0.23 . While the findings of high -level thinking skills also showed no significant difference for pre -test between the control group and the treatment group. Mean for control group (mean $=1.76, \mathrm{sd}=0.41$ ) and treatment group (mean $=1.72, \mathrm{sd}=0.29), \mathrm{t}(29)=0.47, \mathrm{p}$ $\geq 0.05$ i.e. 0.64 . The mean difference of high -level thinking skills between these two groups was 0.39. These findings can be seen through Table 1 and Table 2. This indicates that both groups have similar levels of mathematical achievement and high-level thinking skills. Thus, both groups were considered to have equivalence in both variables.

Table 1

Findings of independent sample t-test analysis for Pre-mathematic achievement test between control group and treatment group

\begin{tabular}{lllllll}
\hline Group & Mean & $\begin{array}{l}\text { Standard } \\
\text { deviation }\end{array}$ & Differences & t & df & Sig. \\
\hline Control & 2.40 & 0.50 & -0.23 & -1.88 & 29 & 0.70 \\
Treatment & 2.63 & 0.49 & & & & \\
\hline
\end{tabular}


INTERNATIONAL JOURNAL OF ACADEMIC RESEARCH IN PROGRESSIVE EDUCATION AND

DEVELOPMENT

Vol. 11, No. 1, 2022, E-ISSN: 2226-6348 @ 2022 HRMARS

Table 2

Independent sample t-test analysis of the pre-test of High Order Thinking Skills between the control group and the treatment group

\begin{tabular}{lllllll}
\hline Group & Mean & $\begin{array}{l}\text { Standard } \\
\text { deviation }\end{array}$ & Differences & $t$ & $\mathrm{df}$ & Sig. \\
\hline Control & 1.76 & 0.41 & 0.39 & 0.47 & 29 & 0.64 \\
Treatment & 1.72 & 0.29 & & & & \\
\hline
\end{tabular}

The second hypothesis for this study was that there was no significant difference in mean scores of achievements and high -level thinking skills between pre -test and post -test in the control group. The findings indicate that the mean comparison in achievement scores and high -level thinking skills in the control group. The results of repeated measurement t-test showed no significant difference of mean score of mathematical achievement score and highlevel thinking skills for the control group between pre-test and post-test. This means that the intervention process carried out did not successfully show changes to both variables. Findings can be seen in Table 3 ( $t(29)=0.81, p \geq 0.05$ which is 0.42 ) and Table 4 ( $t(29)=-1.34, p \geq$ 0.05 which is 0.17 ).

Table 3

Analysis of t-test repeated measurement of mean mathematic achievement test for Pre and Post-test of Control group

\begin{tabular}{lllllll}
\hline Test & Mean & $\begin{array}{l}\text { Standard } \\
\text { deviation }\end{array}$ & Differences & $\mathrm{t}$ & $\mathrm{df}$ & Sig. \\
\hline Pre & 2.40 & 0.50 & 0.07 & 0.81 & 29 & 0.42 \\
Post & 2.33 & 0.48 & & & & \\
\hline
\end{tabular}

Table 4

Analysis of repeated measurement t-test for pre-test and post-test of Higher Order Thinking Skills control group

\begin{tabular}{lllllll}
\hline Test & Mean & $\begin{array}{l}\text { Standard } \\
\text { deviation }\end{array}$ & Differences & t & df & Sig. \\
\hline Pre & 1.76 & 0.41 & -0.15 & -1.34 & 29 & 0.17 \\
Post & 1.91 & 0.40 & & & &
\end{tabular}

The third hypothesis is that there is no significant difference in the mean score of mathematical achievement and high-level thinking skills between pre and post-tests in the treatment group. The results of repeated measurement t-test showed that there was a significant difference between pre-test and post-test for both enablers variables namely mathematical achievement $t(29)=-24.08, p \leq 0.05)$ and high -level thinking skills $t(29)=-$ 41.94, $p=0.00$. Both $p$ values show less than 0.05 . So, there is a significant difference. This can be seen in Table 5 and Table 6. 
INTERNATIONAL JOURNAL OF ACADEMIC RESEARCH IN PROGRESSIVE EDUCATION AND

DEVELOPMENT

Vol. 11, No. 1, 2022, E-ISSN: 2226-6348 @ 2022 HRMARS

Table 5

Analysis of repeated measurement t-tests for mathematic achievement between Pre-and Post-tests of the Treatment group

\begin{tabular}{lllllll}
\hline Test & Mean & $\begin{array}{l}\text { Standard } \\
\text { deviation }\end{array}$ & Differences & $\mathrm{t}$ & $\mathrm{df}$ & Sig. \\
\hline Pre & 2.40 & 0.50 & -0.23 & -1.88 & 29 & 0.70 \\
Post & 2.63 & 0.49 & & & &
\end{tabular}

Table 6

Repeated measurement $t$-test analysis of mean high order thinking skills pre-test and posttest treatment group

\begin{tabular}{lllllll}
\hline Test & Mean & $\begin{array}{l}\text { Standard } \\
\text { deviation }\end{array}$ & Differences & $\mathrm{t}$ & $\mathrm{df}$ & Sig. \\
\hline Pre & 1.72 & 0.29 & -2.81 & -41.94 & 29 & 0.00 \\
Post & 4.53 & 0.30 & & & &
\end{tabular}

The findings show that the flow chart method successfully has a good effect on both variables

The fourth hypothesis was that there was no significant difference in the mean scores of achievements and thinking skills in the post -test between the control and treatment groups. In the findings of the study found that there is a mean difference in mathematical achievement scores and high -level thinking skills for the post-test between the control group and the treatment group. The findings can be seen through Table $7(\mathrm{t}(29)=19.34, \mathrm{p} 0.00)$ and Table $8(t(29)=28.17, p 0.00)$. where both variables have a $p$ value of less than 0.05 .

Table 7

Independent sample t-test analysis for post-test of mathematic achievement between Control group and Treatment group

\begin{tabular}{lllllll}
\hline Group & Mean & $\begin{array}{l}\text { Standard } \\
\text { deviation }\end{array}$ & Differences & t & df & Sig. \\
\hline Control & 2.33 & 0.48 & -2.30 & -19.34 & 29 & 0.00 \\
Treatment & 4.63 & 0.49 & & & & \\
\hline
\end{tabular}

Table 8

Post-test independent $t$-test analysis of high order thinking skills between the Control group and the Treatment group in the post-test

\begin{tabular}{lllllll}
\hline Group & Mean & $\begin{array}{l}\text { Standard } \\
\text { deviation }\end{array}$ & Differences & $\mathrm{t}$ & $\mathrm{df}$ & Sig. \\
\hline Control & 1.91 & 0.40 & -2.62 & -28.17 & 29 & 0.00 \\
Treatment & 4.53 & 0.30 & & & & \\
\hline
\end{tabular}

Thus, the flow map method has had a positive effect on students 'mathematical achievement and high -level thinking skills. 
DEVELOPMENT

Vol. 11, No. 1, 2022, E-ISSN: 2226-6348 @ 2022 HRMARS

\section{Discussion and Conclusion}

The use of the flow chart method implemented in this study is indeed effective for third year students on two main variables, namely mathematical achievement and high -level thinking skills. This study also contributes to the use of teaching techniques as implemented by (Muhamad et al., 2018; Afifi et al., 2019). If a transformation is made to a teaching approach, method or technique. Thus, a positive impact will result.

Thus, the flow map method can be used by teachers to teach students to solve sentence problem -solving questions in addition operations. These skills are very important to be mastered by students so that they do not fall behind in mathematics. These skills are fundamental to other skills in mathematics (Yazgan, 2015; Hassan et al., 2019). If students can master mathematical problem -solving skills, they can also master high -level thinking skills (Ismail et. al., 2020).

The flow map method introduced has systematic steps that can be used as a guide by students. This method is also suitable to be practiced by teachers during the teaching and learning process. Teachers can act as facilitators as suggested by (Abdullah et al., 2019). Thus, teachers can diversify methods to help students in mastering and solving verse math problems. This method can be used as an alternative method by teachers. It is hoped that this will help the country to achieve the aspirations of students indirectly so that international assessment scores such as Trends in International Mathematics and Science Study (TIMSS) and the Program for International Student Assessment (PISA) can be improved.

In conclusion, the use of flow map method in sentence problem solving questions can help students deal with mathematics learning problems. Pupils are also able to improve their math achievement scores and master high order thinking skills. Therefore, Mathematics teachers need to use interesting, creative and innovative teaching methods in the teaching of mathematics learning. Questions in the form of daily life can be constructed and solved using this flow chart method. This in turn gives a clear picture to students that mathematics exists in their daily lives. The use of this method may also be able to increase student motivation. Therefore, research related to motivation can be conducted later. This method contributes towards the development of national aspirations.

\section{References}

Abdullah, M. Z., Daud, I., Idris, M. R., \& Rahman, M. N. A. (2019). Kesan pembelajaran flipped classroom terhadap sikap bagi penyelesaian masalah bagi algebra, Jurnal Kurikulum \& Pengajaran Asia Pasifik, 7(4), 1-10.

Ariffin, N. E., \& Hj. Azid Aziz, N. (2016). Persepsi Murid Tahun Lima Terhadap Penggunaan Kaedah Model Bar Dalam Penyelesaian Masalah Matematik Berayat Tajuk Pecahan. Proceedings of The International Seminar on Generating Knowledge Through Research (ICECRS), 1(1), 287-304. https://doi.org/10.21070/picecrs.v1i1.613

Bachri, B. S., \& Nurdyansyah. (2017). Problem solving model with integration pattern: student's problem-solving capability, Education and Humanities Research. Retrieved from file:///C:/Users/hp/Downloads/Problem_Solving_Model_with_Integration_Pat tern_Stu.pdf

Campbell, D. T., \& Stanley, J. C. (1963). Experimental And Quasi-Experimental Designs For Research. Boston: Houghton Mifflin Company. 
DEVELOPMENT

Vol. 11, No. 1, 2022, E-ISSN: 2226-6348 @ 2022 HRMARS

Coakes, S. J. (2007). Analysis Without Anguish: Version 12.0 For Windows. Singapore: John Wiley \& Sons Inc.

Cohen, L., Manion, L., \& Morrison, K. (2007). Research Methods In Education (6th ed.). Abingdon: Routledge Taylor \& Francis Group.

Creswell, J. W. (2012). Educational Research: Planning, Conducting, And Evaluating Quantitative And Qualitative Research. Educational Research (4th ed.). Boston: Pearson Education Inc.

Fraenkal, J. R., Wallen, N. E., \& Hyun, H. H. (2012). How To Design And Evaluate Research In Education (8th ed.). New York: McGraw-Hill. http://doi.org/ 10.1037/032719

Gay, L. R., Mills, G. E., \& Airasian, P. (2009). Education Research: Competencies For Analysis And Applications (9th ed.). New Jersey: Pearson Education.

Gelerstein, D., Rio, R. del, Nussbaum, M., \& Chiuminatto, P. (2016). Designing And Implementing A Test For Measuring Critical Thinking In Primary School. Thinking Skills and Creativity. http://doi.org/10.1016/j.tsc.2016.02.002

Hassan, N. H., Hussin, Z., Siraj, S., Sapar, A. A., \& Ismail, Z. (2019). Kemahiran berfikir kritis dalam buku teks bahasa melayu kurikulum standard sekolah rendah tahap II. Jurnal Kurikulum \& Pengajaran Asia Pasifik, 7(1), 18-29.

Ismail, F., Nasir, A. A., Haron, R., \& Kelewon, N. A. (2020). Mendominasi kemahiran penyelesaian masalah secara kritis melalui penglibatan mahasiswa dalam kokurikulum bulan sabit merah Malaysia. Research in Management of Technology and Business. Diperolehi dari https://publisher.uthm.edu.my/

Malaysia Education Ministry. (1994). Thinking skills. Curriculum Development Centre. Kuala Lumpur: Ministry of Education Malaysia.

Malaysia Education Ministry. (2006). Education Development Master Plan. Putrajaya: Ministry of Education Malaysia.

Malaysia Education Ministry. (2007). National Higher Education Strategic Plan. Putrajaya: Ministry of Education Malaysia.

Afifi, M. B. S., Nor'ain, M. T., Faiz, M. Y., \& Ikhwan, M. S. (2019). Adventure learning in basics statistics: Impact on students critical thinking. International Journal of Instruction, 12(3), 151-166. https://doi.org/10.29333/iji.2019.12310a

Muhamad, N., Zakaria, M. A., Salleh, S. M., \& Harun, J. (2018). Penggunaan permainan digital dalam pembelajaran bilik darjah bagi meningkatkan kreativiti dalam penyelesaian masalah matematik. Fakulti Sains Sosial dan Kemanusian. Universiti Teknologi Malaysia.

Hidayah, N., \& Zanaton. (2017). Strategi metakognitif dan kemahiran berfikir aras tinggi dalam proses pengajaran dan pembelajaran. Simposium Pendidikan diPeribadikan: Fakulti Pendidikan. Universiti Kebangsaan Malaysia

Polya, G. (1957). How to solve it. Princeton: Princeton University Press.

Salleh, S. (2016). Kemahiran penyelesaian masalah dalam tajuk nombor bulat dan pecahan dalam kalangan murid tahun lima. Tesis Ijazah Sarjana Muda Sains Dan Komputer Serta Pendidikan (Matematik). Universiti Teknologi Malaysia.

Yap, J. L., \& Rahaimah, S. A. (2018). Keberkesanan pendekatan model bar dalam penyelesaian masalah berayat matematik operasi tolak tahun empat. Jurnal Pendidikaan Sains \& Matematik. 8(2) 35-44.

Yazgan, Y. (2015). Sixth graders non-routine problems: which strategies are decisive for success. European Journal of Education Studies. 2(4), 100-120. 